\title{
Spatial distribution and abundance of Channa striata Bloch1793 in Sempor Reservoir, Kebumen Central Java
}

\author{
Nuning Setyaningrum ${ }^{1, *}$, Agus Nuryanto $^{2}, W$. Lestari ${ }^{2}$, Krismono $^{3}$ \\ ${ }^{1}$ Postgraduate Program Faculty of Biology, Jenderal Soedirman University, Purwokerto, Indonesia \\ ${ }^{2}$ Biology Faculty, Jenderal Soedirman University, Purwokerto 53122, Indonesia \\ ${ }^{3}$ Research Institute for Fisheries Enhancement (RIFE), Ministry of Marine Affairs and Fisheries, \\ Jl. Cilalawi No. 01 Jatiluhur, Purwakarta, West Java 41152 - Indonesia
}

\begin{abstract}
Channa striata are one of the essential catches in freshwater, including Sempor Reservoir. This study aimed to investigate the spatial distribution and abundance of Channa striata and the correlation between the abundance of snakehead and water quality parameters. The study was undertaken in Sempor Reservoir Central Java from March to October 2020. The method included a survey with five Stations of sampling. Distribution data were tabulated using the Microsft Excel program. Data of abundance and water quality were subjected to ANOVA. The correlation between the abundance and water quality was analyzed with the Principle Component Analysis (PCA). The result showed that the distribution of snakehead fish in Sempor Reservoir covered a wide range across the inlets, middle, outlets, and beyond the dam. The catch fish was $110-390 \mathrm{~mm}$ long and weighed 12$588 \mathrm{~g}$. The male and female fish percentage was $55.68 \%$ vs $44.32 \%$, so the female to male ratio was $0.8: 1$. The highest abundance of snakehead fish was in the KW station (33\%). The distribution of C.striata was more affected by the fish behaviour in selecting their habitat than the water temperature, depth, and transparency. The significance of this study expects to lay the foundation for snakehead fisheries management in Sempor Reservoir.
\end{abstract}

\section{Introduction}

Channa striata are freshwater fish with various habitats from the river, lake, dam, swamp, ricefield, to ditch. Generally, this fish is widely distributed across South Asia, Central Asia, and Southeast Asia from Thailand to Indonesia [1]. In Indonesia, C.striata is native to the inland waters in Sunda Shelf (Sumatera, Java, and Kalimantan) and inhabits almost all waters in Indonesia. This fish has been introduced to Wallacea waters (Sulawesi, Lesser Sundas, Maluku) and Sahul Shelf (Papua) [2]. In Java, C.striata is distributed in ebb or flow waters, namely Cileumeuh River, in Majenang Subdistrict, and Cikawung River in Cilacap District,

\footnotetext{
* Corresponding author: nuning.setyaningrum67@gmail.com
} 
Central Java [3] [4], Rawa Pening Lake in Central Java [5] and Cilodong Lake, Bogor [6]. To date, the distribution of snakehead fish in dam waters remains unknown.

A dam is a concave formed to hold several rivers with one primary function, i.e., to contain water for irrigation or hydropower (PLTA). The dam is responsible for altering the spatial pattern in water debit, which means a change of habitat that will affect the behaviour and distribution of fish, including C.striata [7] [8].

Sempor Reservoir is formed by damming Cincingguling River, Sempor River, Mampang River, and Kedungwringin River. The reservoir is the essential habitat for fish species, including snakehead fish, and the land use activities can affect the abundance of snakehead fish. A previous study [9] reported that the snakehead fish catch in Sempor Reservoir is as low as $0,68 \%$ of 14 species. This low abundance is due to the disappearing habitat for spawning and rearing, diminished water quality, and water fluctuation [10].

The land around Sempor reservoir is for human residence, pine and teak forests, recreation sites, and floating net cages that affect the reservoir quality. Water condition primarily determines the abundance and distribution of the inhabiting organisms; however, each organism has its preference and need for an environment with specific characteristics for living [11]. As a native species, Snakehead fish is vulnerable to extinction due to anthropogenic factors that threaten its population.

Natural topography and hydrology alteration can affect the abundance of snakehead fish in the Sempor Reservoir. As a result, the ecological function of the dam will change and experience environmental pressures because of human activity. Even worse, the ecological processes of the Sempor Reservoir potentially disappear, leading to the decreased dish species and hence, catching fish. Accordingly, it is vital to probe into the spatial distribution and abundance of C.striata in the Sempor Reservoir.

This study aimed to investigate the spatial distribution and abundance of snakehead fish and the correlation between the distribution and abundance of snakehead fish with water quality that determines the characteristics of the habitat in Sempor Reservoir. Also, our findings expect to be the underpinning fundamental for snakehead fish management in the Sempor Reservoir.

\section{Materials and methods}

\subsection{Sampling size and habitat qualification}

The study was undertaken in Sempor Reservoir, Sempor Subdistrict, Kebumen, Central Java for eight months (March - October 2020). Applying Purposive Random Sampling, we collected C. striata and water quality samples from five stations (Fig. 1.). The habitat characteristics were determined based on the land use activity and vegetation cover according to the habitat of snakehead fish and sampling efficiency (Table 1). 

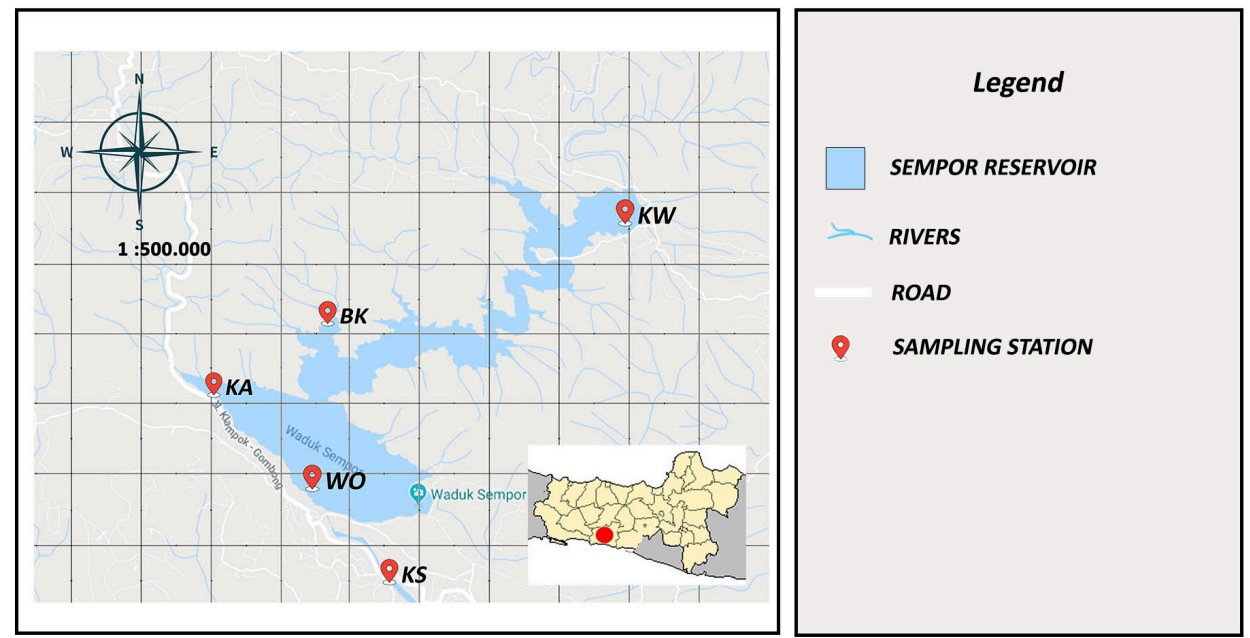

Fig. 1. Research sampling station at Sempor Reservoir.

Table 1. Research sampling station in Sempor Reservoir.

\begin{tabular}{|c|c|c|}
\hline No. & Station & Habitat Characteristics \\
\hline 1. & $\begin{array}{l}\text { Kedungwringin } \\
\text { Station (KW) }\end{array}$ & $\begin{array}{l}\text { a. Agricultural land and residential area around the river } \\
\text { b. Vegetation cover: water shrubs }\end{array}$ \\
\hline 2. & $\begin{array}{l}\text { Bangkong Station } \\
\text { (BK) }\end{array}$ & $\begin{array}{l}\text { a. Teak and pine forests, a large quantity of litterfall, evidence of } \\
\text { monkeys, Javan pond herons, egrets, and boars in the forest. } \\
\text { b. Vegetation cover: water grass and water shrubs }\end{array}$ \\
\hline 3. & $\begin{array}{l}\text { Kalianget Station } \\
\text { (KA) }\end{array}$ & $\begin{array}{l}\text { a. Woody plants, e.g., pine. Along the riverbank are water shrubs } \\
\text { and plantation trees, like bananas and coconut. There is a } \\
\text { residential area and fishing activity. } \\
\text { b. Vegetation cover: water shrubs, e.g., queen crape myrtle and } \\
\text { sensitive plant. }\end{array}$ \\
\hline 4. & $\begin{array}{l}\text { Dam Outlet Station } \\
\text { (WO) }\end{array}$ & $\begin{array}{l}\text { a. Near the outlet is a dam, shared for dock and fishing spot. } \\
\text { b. Vegetation cover: water grass and shrubs }\end{array}$ \\
\hline 5. & $\begin{array}{l}\text { Kali } \quad \text { Sempor } \\
\text { Station }(\mathrm{KS})\end{array}$ & $\begin{array}{l}\text { a. Land for courtyard plants and residential area. c. Vegetation } \\
\text { cover: hydrilla and water weed. }\end{array}$ \\
\hline
\end{tabular}

\subsection{Sampling}

The snakehead fish were caught using fishing rods and fishing guns with different hook sizes. The length and weight of the fish sample were measured, and the fish were dissected to identify the sex. The physical and chemical parameters were measured in situ: $\mathrm{DO}, \mathrm{pH}$, depth, transparency, water flow speed, DO, and ex-situ: TSS, TDS, BOD, COD, $\mathrm{NH}_{3}, \mathrm{NO}_{2}, \mathrm{NO}_{3}$, $\mathrm{PO}_{4}$.

\subsection{Data analysis}

The total length and weight of the fish (sex-based) were input into frequency distribution tables with an interval of $0.5 \mathrm{~cm}$ in the Microsoft Excel program. The spatial distribution and water quality were subjected to ANOVA analysis using SPSS version 24. The correlation 
between the abundance of snakehead fish and water quality was analyzed using the Principal Component Analysis (PCA) software Past 3.

\section{Results}

C.striata caught in Sempor Reservoir as many as 88 individuals were found at Kedungwringin station (KW): 29 individuals, Kalianget (KA): 12 individuals, Bangkong (BK): 10 individuals, Reservoir outlet: (WO): 12 individuals and Sempor River (KS): 25 individuals. The percentage of C.striata population based on sex distribution was higher in females $(55,68 \%)$ than the males $(44,32 \%)$ across four stations, except for KS station the number of males and females was equal. Overall the average sex ratio of males and females in the Sempor Reservoir is $0.8: 1$ (Table 2). However, the statistical analysis showed a balanced male to female ratio $(\mathrm{P}>0,05)$.

Table 2. Percentage of male and females at five stations in Sempor Reservoir.

\begin{tabular}{|c|c|c|c|c|c|c|}
\hline Station & Male & Female & $\begin{array}{c}\text { Number of } \\
\text { Fish }\end{array}$ & \% Male & \% Female & Sex Ratio \\
\hline KW & 13 & 16 & 29 & 44.83 & 55.17 & $0,8: 1$ \\
\hline BK & 4 & 6 & 10 & 40.00 & 60.00 & $0,7: 1$ \\
\hline KA & 5 & 7 & 12 & 41.67 & 58.33 & $0,7: 1$ \\
\hline WO & 4 & 8 & 12 & 33.33 & 66.67 & $0,5: 1$ \\
\hline KS & 13 & 12 & 25 & 52.00 & 48.00 & $1,1: 1$ \\
\hline & 39 & 49 & 88 & 44.32 & 55.68 & $0,8: 1$ \\
\hline
\end{tabular}

Note: KW: Kedungwringin, BK: Bangkong, BK: KA: Kalianget, WO: Waduk Outlet, KS: KaliSempor

The length-frequency distribution of C.striata showed that the shortest fish (110-149 mm) (nine fish) was spotted in KS station while the longest (390-429 mm) was spread in KW stations (four fish), BK station (one fish), and KA station (one fish). Meanwhile, most fish caught in these five stations were 230-269 mm long (26,14\%) (Table 3).

Table 3. Spatial distribution of C.striata by the length in Sempor Reservoir.

\begin{tabular}{|c|c|c|c|c|c|c|c|c|}
\hline \multirow[t]{2}{*}{ No. } & \multirow{2}{*}{$\begin{array}{c}\text { Fish Length } \\
(\mathrm{mm})\end{array}$} & \multicolumn{5}{|c|}{ Station } & \multirow[t]{2}{*}{ Number } & \multirow{2}{*}{$\begin{array}{c}\% \\
\text { Number } \\
\end{array}$} \\
\hline & & KW & BK & KA & WO & KS & & \\
\hline 1 & $110-149$ & 0 & 0 & 0 & 0 & 2 & 2 & 2.27 \\
\hline 2 & $150-189$ & 2 & 0 & 0 & 0 & 2 & 4 & 4.55 \\
\hline 3 & $190-229$ & 3 & 0 & 3 & 6 & 4 & 16 & 18.18 \\
\hline 4 & $230-269$ & 8 & 3 & 1 & 2 & 9 & 23 & 26.14 \\
\hline 5 & $270-309$ & 8 & 1 & 4 & 2 & 6 & 21 & 23.86 \\
\hline 6 & $310-349$ & 2 & 2 & 3 & 1 & 2 & 10 & 11,36 \\
\hline 7 & $350-389$ & 2 & 3 & 0 & 1 & 0 & 6 & 6.82 \\
\hline 8 & $390-429$ & 4 & 1 & 1 & 0 & 0 & 6 & 6.82 \\
\hline
\end{tabular}

Note: KW: Kedungwringin, BK: Bangkong, BK: KA: Kalianget, WO: Waduk Outlet, KS: Kali Sempor

Weight-frequency distribution of C.striata showed that the smallest fish (12-89 g) were spotted in KS station, while the biggest ones (558-635 g) were found in KW station (three fish), BK (one fish), and KA (one fish). The weight of most of the fish caught in five stations was $90-167 \mathrm{~g}(26,14 \%)$ (Table 4$)$. 
Table 4. Spatial distribution of C.striata by weight in Sempor Reservoir.

\begin{tabular}{|c|c|c|c|c|c|c|c|c|}
\hline \multirow[t]{2}{*}{ No. } & \multirow{2}{*}{$\begin{array}{c}\text { Fish weight } \\
\text { (g) }\end{array}$} & \multicolumn{5}{|c|}{ Station } & \multirow[t]{2}{*}{ Number } & \multirow{2}{*}{$\begin{array}{c}\% \\
\text { Number }\end{array}$} \\
\hline & & KW & BK & KA & WO & $\mathrm{KS}$ & & \\
\hline 1 & $12-89$ & 0 & 0 & 0 & 0 & 2 & 2 & 2.27 \\
\hline 2 & $90-167$ & 10 & 3 & 4 & 8 & 13 & 38 & 43.18 \\
\hline 3 & $168-245$ & 11 & 1 & 4 & 2 & 8 & 26 & 29.55 \\
\hline 4 & $246-323$ & 2 & 2 & 2 & 1 & 1 & 8 & 9.09 \\
\hline 5 & $324-401$ & 0 & 2 & 1 & 0 & 1 & 4 & 4.55 \\
\hline 6 & $402-479$ & 1 & 1 & 0 & 1 & 0 & 3 & 3.41 \\
\hline 7 & $480-557$ & 2 & 0 & 0 & 0 & 0 & 2 & 2.27 \\
\hline 8 & $558-635$ & 3 & 1 & 1 & 0 & 0 & 5 & 5.68 \\
\hline
\end{tabular}

Note: KW: Kedungwringin, BK: Bangkong, BK: KA: Kalianget, WO: Waduk Outlet, KS: Kali Sempor

Table 5. Spatial distribution of male and female C.striata (\%) by the length in Sempor Reservoir.

\begin{tabular}{|c|c|c|c|c|c|c|c|c|c|c|c|}
\hline \multirow[t]{3}{*}{ No. } & \multirow{3}{*}{$\begin{array}{l}\text { Fish Length } \\
(\mathrm{mm})\end{array}$} & \multicolumn{10}{|c|}{ Station } \\
\hline & & \multicolumn{2}{|c|}{ KW } & \multicolumn{2}{|c|}{ BK } & \multicolumn{2}{|c|}{ KA } & \multicolumn{2}{|c|}{ WO } & \multicolumn{2}{|c|}{ KS } \\
\hline & & $\hat{0}$ & o & $\hat{0}$ & ㅇ & $\hat{\sigma}$ & o & $\hat{0}$ & o & $\hat{0}$ & q \\
\hline 1 & $110-149$ & 0 & 0 & 0 & 0 & 0 & 0 & 0 & 0 & 0 & 2.27 \\
\hline 2 & 150-189 & 3.41 & 1.14 & 0 & 0 & 0 & 0 & 0 & 0 & 0 & 4.55 \\
\hline 3 & $190-229$ & 1.14 & 0 & 0 & 0 & 1.14 & 2.27 & 2.27 & 4.55 & 2.27 & 0 \\
\hline 4 & $230-269$ & 2.27 & 6.82 & 1.14 & 2.27 & 1.14 & 0 & 0 & 2.27 & 3.41 & 6.82 \\
\hline 5 & $270-309$ & 5.68 & 3.41 & 1.14 & 0 & 1.14 & 3.41 & 1.14 & 1.14 & 1.14 & 5.68 \\
\hline 6 & $310-349$ & 0 & 2.27 & 0 & 2.27 & 0 & 3.41 & 0 & 1.14 & 0 & 2.27 \\
\hline 7 & $350-389$ & 0 & 2.27 & 2.27 & 1.14 & 0 & 0 & 0 & 1.14 & 0 & 0 \\
\hline 8 & $390-429$ & 1.14 & 3.41 & 0 & 1.14 & 0 & 1.14 & 0 & 0 & 0 & 0 \\
\hline
\end{tabular}

Note: KW: Kedungwringin, BK: Bangkong, BK: KA: Kalianget, WO: Waduk Outlet, KS: Kali Sempor

The sex-spatial distribution of C.striata showed that most males were found in KW stations $(5,68 \%)$ with a length of $270-309 \mathrm{~mm}$ while the females dominated the population in KW and KS stations $(6,82 \%)$ with the length of 230-269 $\mathrm{mm}$ (Table 5). The weightfrequency distribution of male C.striata $(12,5 \%)$ and their female counterparts $(7,95 \%)$ were primarily found in KS station where the male and female fish weighed 150-189g and 190$229 \mathrm{~g}$, respectively (Table 6).

Table 6. Spatial distribution of male and female C.striata (\%) by weight in Sempor Reservoir.

\begin{tabular}{|c|c|c|c|c|c|c|c|c|c|c|c|}
\hline \multirow{2}{*}{ No. } & \multirow{2}{*}{ Fish weight (g) } & \multicolumn{9}{|c|}{ Station } & \multicolumn{3}{c|}{ KS } \\
\cline { 3 - 13 } & & \multicolumn{2}{|c|}{ KW } & \multicolumn{3}{c|}{ BK } & \multicolumn{3}{c|}{ KA } & \multicolumn{3}{c|}{ WO } & \multicolumn{2}{c|}{ KS } \\
\cline { 3 - 13 } & & 0 & + & 0 & 0 & 0 & + & 0 & + & 0 & + \\
\hline 1 & $110-149$ & 0 & 0 & 0 & 0 & 0 & 0 & 0 & 0 & 1.14 & 0 \\
\hline 2 & $150-189$ & 6.82 & 4.55 & 1.14 & 2.27 & 3.41 & 1.14 & 2.27 & 6.82 & 12.5 & 3.41 \\
\hline 3 & $190-229$ & 5.68 & 6.82 & 1.14 & 0 & 1.14 & 3.41 & 1.14 & 1.14 & 1.14 & 7.95 \\
\hline 4 & $230-269$ & 0 & 2.27 & 0 & 2.27 & 0 & 2.27 & 0 & 1.14 & 0 & 1.14 \\
\hline 5 & $270-309$ & 0 & 0 & 2.27 & 0 & 0 & 1.14 & 0 & 0 & 0 & 1.14 \\
\hline 6 & $310-349$ & 0 & 1.14 & 0 & 1.14 & 0 & 0 & 0 & 1.14 & 0 & 0 \\
\hline 7 & $350-389$ & 1.134 & 1.134 & 0 & 0 & 0 & 0 & 0 & 0 & 0 & 0 \\
\hline 8 & $390-429$ & 0 & 3.41 & 0 & 1.14 & 0 & 1.14 & 0 & 0 & 0 & 0 \\
\hline
\end{tabular}

Note: KW: Kedungwringin, BK: Bangkong, BK: KA: Kalianget, WO: Waduk Outlet, KS: Kali Sempor

Fig. 2. shows that most C.striata (32,95\%) are found in Kedungwringin Station (KW), followed by KS $(28,41 \%)$, WO, and KA $(13,64 \%)$, and the least $(11,36 \%)$ in Bangkong Station (BK). The result of ANOVA showed that the abundance of fish across five stations was not significantly $(\mathrm{P}>0,05)$ different. 


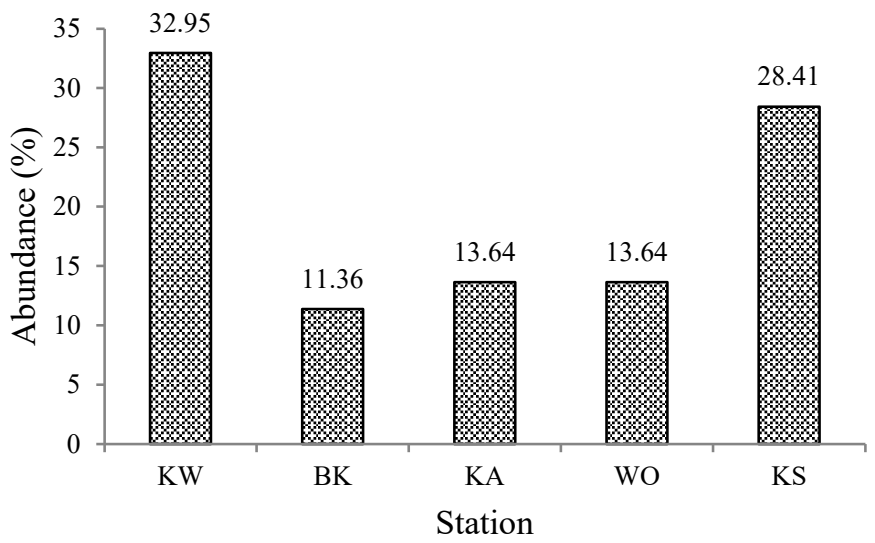

Fig. 2. The abundance of C. striata in Sempor Reservoir.

The average score of water quality as an environmental factor fluctuates in each station (Table 7). The correlation between water quality and fish abundance was analyzed using the Principal Components Analysis (PCA) with Software Past 3.

Table 7. Water quality in Sempor Reservoir.

\begin{tabular}{|c|c|c|c|c|c|}
\hline \multirow{2}{*}{ Parameter } & \multicolumn{5}{|c|}{ Station } \\
\cline { 2 - 6 } & KW & BK & KA & WO & KS \\
\hline Physical & & & & & \\
\hline $\begin{array}{c}\text { Temperature } \\
\left({ }^{\circ} \mathrm{C}\right)\end{array}$ & $31.2-32.3$ & $29.6-30.5$ & $29.3-31.1$ & $28.9-30.2$ & $27.4-30.2$ \\
\hline Depth (m) & $0.5-1$ & $6.1-8.7$ & $4.5-9.8$ & $5.2-8.3$ & $0.4-2.2$ \\
\hline $\begin{array}{c}\text { Transparency } \\
(\mathrm{m})\end{array}$ & $0.3-0.8$ & $1.21-2.66$ & $0.94-2.26$ & $1.33-2.57$ & $0.39-2.0$ \\
\hline $\begin{array}{c}\text { Water flow } \\
\text { speed (m/s) }\end{array}$ & $0.01-0.03$ & $0.01-0.3$ & $0.02-0.1$ & $0.01-0.4$ & $0.01-0.1$ \\
\hline TSS (mg/l) & $147.25 \pm 45$ & $136.25 \pm 34$ & $139.25 \pm 44$ & $127.25 \pm 32$ & $136.25 \pm 48$ \\
\hline $\mathrm{TDS}$ & $204.25 \pm 25.11$ & $175.5 \pm 31.32$ & $195 \pm 47.56$ & $178.75 \pm 37.32$ & $201.5 \pm 50,3$ \\
\hline Chemical & & & & & \\
\hline $\mathrm{DO}(\mathrm{mg} / \mathrm{l})$ & $8.16 \pm 2.5$ & $8.74 \pm 1,9$ & $8.2 \pm 2.8$ & $8.4 \pm 2.2$ & $6.7 \pm 1.6$ \\
\hline $\mathrm{pH}$ & $8.0 \pm 0.2$ & $8.4 \pm 0.3$ & $8.5 \pm 0.27$ & $8.1 \pm 0.7$ & $7.9 \pm 0.3$ \\
\hline $\mathrm{BOD}(\mathrm{mg} / \mathrm{l})$ & $4.72 \pm 0.5$ & $4.11 \pm 0.6$ & $4.17 \pm 0.7$ & $3.78 \pm 0.7$ & $5.01 \pm 0.4$ \\
\hline $\mathrm{COD}(\mathrm{mg} / \mathrm{l})$ & $14.4 \pm 1.85$ & $11.71 \pm 0.1$ & $12.47 \pm 1.9$ & $11.42 \pm 1.5$ & $13.9 \pm 0.9$ \\
\hline $\mathrm{NO}_{2}-\mathrm{N}(\mathrm{mg} / \mathrm{l})$ & $0.0223 \pm 0.003$ & $0.0228 \pm 0.007$ & $0.0183 \pm 0.006$ & $0.022 \pm 0.002$ & $0.017 \pm 0.001$ \\
\hline $\mathrm{NO}_{3}-\mathrm{N}(\mathrm{mg} / \mathrm{l})$ & $0.702 \pm 0.15$ & $0.746 \pm 0.07$ & $0.693 \pm 0.23$ & $0.67 \pm 0.04$ & $0.649 \pm 0.11$ \\
\hline $\mathrm{NH}_{3}-\mathrm{N}(\mathrm{mg} / \mathrm{l})$ & $0.0245 \pm 0.007$ & $0.025 \pm 0.007$ & $0.021 \pm 0.067$ & $0.0235 \pm 0.005$ & $0.026 \pm 0.007$ \\
\hline $\mathrm{PO}_{4}-\mathrm{P}(\mathrm{mg} / \mathrm{l})$ & $0.2125 \pm 0.07$ & $0.22175 \pm 0.06$ & $0.2213 \pm 0.05$ & $0.214 \pm 0.04$ & $0.1675 \pm 0.04$ \\
\hline
\end{tabular}

Note: KW: Kedungwringin, BK: Bangkong, BK: KA: Kalianget, WO: Waduk Outlet, KS: Kali Sempor

The result of ANOVA indicated a significant $(\mathrm{P}<0,05)$ difference in water quality across stations observed from the physical elements, i.e., temperature, depth, and clarity. The lowest water temperature $\left(27.4^{\circ} \mathrm{C}\right)$ was in $\mathrm{KS}$, and the highest $\left(32.3^{\circ} \mathrm{C}\right)$ was $\mathrm{KW}$. The water depth in $\mathrm{KW}$ and $\mathrm{KS}$ were generally low, with an average of $0.70 \mathrm{~m}$ and $1.3 \mathrm{~m}$, respectively, followed by a relatively low clarity compared to the other three stations. 
The correlation between water quality and the abundance of C.striata is illustrated with a biplot in five stations. (Fig. 3.) shows that the abundance of snakehead fish is positively correlated with TSS, TDS, NO2 BOD, and COD parameters, but the closest ones are TSS and TDS. The abundance of snakehead fish would be higher in stations with higher TSS, TDS, $\mathrm{NO}_{2} \mathrm{BOD}$, and COD, such as KW, KA, and KS stations. The abundance of snakehead fish is negatively correlated with the water flow and depth. Stations with rapid flow and deep water have a small quantity of snakehead fish.

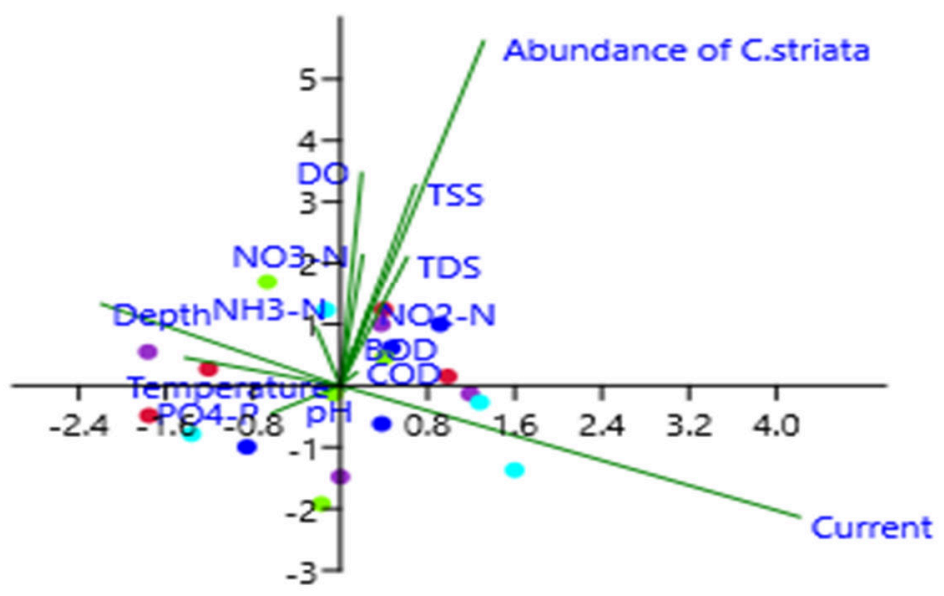

Fig. 3. The correlation between water quality and the abundance of C.striata in Sempor Reservoir.

\section{Discussion}

C. striata were found in all observatory stations. It shows that the fish are widely spread in Sempor reservoir, from the inlet (KW and KA stations), middle (station BK), to the outlet (station WO), and beyond the dam (station KS). C. striata can live in different habitats because they have enough slime for the dry season and additional diverticula in the respiratory system, enabling them to adapt to the low-oxygen condition. According to [28], $C$. striata can directly inhale oxygen from the air and live under a hypoxia state. $C$. striata are prevalent in different bodies of water, from lentic water (lake, reservoir, dam, swamp) [1] [12] [13] [5] [6], to lotic water, e.g., river or ditch [14] [3] [4] [15].

The ratio of male and female fish in this study was $0.8: 1$, the number of females was more than males, but based on statistical tests, there was equilibrium in five stations. Based on several studies, the male-to-female ratio of C. striata can be said to be balanced with females more than males, namely 1:1,6 in Bangladesh lentic ecosystem [18], 1:1,5 in Taiwan wetland and dams [19], and 0,6:1,0 in the floodplain of Sebangau watershed, Palangkaraya [20]. However, the female dominance showed that the population of $C$. striata in Sempor Reservoir is still ideal for preservation, although it is lower than C. striata in Rawa Pening Lake, Semarang, Central Java, i.e., 1:2,14, [5]. The balanced sex ratio of snakehead fish across all stations of Sempor Reservoir showed that reproduction would continue to occur so that the population is maintained under steady conditions. If there are more female fish than male fish, there will be recruitment in the waters. Previous studies reported different ratios where males outnumbered females, namely 1,14:1 in the floodplain of Musi River [16] and 
1:0,5 in Assam water, India [17]. In contrast, according to Saputra [21], a balanced male: female ratio or more female than male indicates an ideal population in water, thus avoiding extinction.

The size of fish in all five stations is $110-390 \mathrm{~mm}$ long, and they weigh $12-558 \mathrm{~g}$. It illustrates a low diversity compared to C.striata caught in the floodplain of Lubuk Lampam, South Sumatera, namely 51-700 mm long and weigh 7-2.997 gram [22], the floodplain of Musi river, i.e., 11-495 mm [23], and Rawa Pening, 240-600mm [5]. Accordingly, the diversity of C.striata in Sempor reservoir, Central Java, from the smallest to the biggest fish, is inferior to Sumatera and Kalimantan. It shows that swamp is the more suitable habitat for snakehead fish, evident from the abundance of fish in the swamp [1] [12] [28].

Fish sized 230-349 $\mathrm{mm}$ are found in all stations, while the 110-149 $\mathrm{mm}$ (the shortest size) is only observed in the KS station. Fish size is a crucial indicator of the maturity level and age of a fish. The ANOVA result is related to the abundance of fish in all five stations, which was not significantly different $(\mathrm{P}>0,05)$. However, the $\mathrm{KW}$ station shows the highest abundance with a broader range of length and weight. Meanwhile, the lowest abundance was observed in the BK station, where fish size ranged from 230 to $429 \mathrm{~mm}$ long and weighed 90 $\mathrm{g}$ to $558 \mathrm{~g}$. The shortest and lightest C.striata were found in the KS station, which indicates the addition of small fish into the dam that are underqualified for a catch. KW station has snakehead fish of various lengths and weights, probably because KW station is the primary habitat for snakehead fish. This study shows that snakehead fish caught in Sempor reservoir are longer than those in the floodplain of Musi River, namely 140-189 mm [24] and 200-280 $\mathrm{mm}[23]$.

The length and weight of snakehead fish in the Sempor reservoir generally belongs to big fish for consumption. However, some fish are found to be in the reproductive stage, so fishing restriction is needed to preserve the abundance. The sex-based distribution indicates that female fish sized 310-429 mm belongs to the big category and is found in KW station that probably undergoes gonad maturity stage. Female and male snakehead fish enter the first gonad maturity at $210 \mathrm{~mm}$ and $185 \mathrm{~mm}$, respectively, in the floodplain of Musi River [23], and $227,5 \mathrm{~mm}$ and $322 \mathrm{~mm}$, respectively floodplain of Sebangau River watershed, Palangkaraya [20]. Therefore, the KW station is proper for spawning habitat for snakehead fish because it is part of the river estuary of Mampang River and Kedungjati River that provides abundant natural food for snakehead fish. This study supported [20] that the spawning site of snakehead fish is situated downstream of the floodplain in Sebangau River watershed, Palangkaraya. The distribution and abundance of fish are significantly affected by their habitat and environment [25].

The abundance of C.striata in $\mathrm{KW}$ station is the highest because it is the river inlet where many rivers, including the Mampang River and Kedungjati River, meet. KW station is a relatively large dam that flows its abundant water into the Sempor reservoir. The land use activity around the KW station includes agricultural land and rice field, and the vegetation cover includes shrubs. KW station belongs to a transition zone, thus more fish species, including C.striata. Also, transition zones are heterogeneous habitats that provide food sources for the fish and a spawning site [26] [7]. The abundance of C.striata is probably due to the influx of nutrients from the Mampang River and Kedungjati River into the KW station. This habitat is where C.striata feed, spawn and grow. The BK station has the lowest abundance of C.striata because it is located in a separate area from the other stations, so only a few water plants are inhabited by the fish. The land around BK station is pine forest with less anthropogenic and fishing activity by the surrounding community. Fish caught in BK generally show active reproduction (230-429mm long), so this habitat needs protection. Any alteration in water habitat due to human activity along the banks, such as residential areas, agriculture, transportation, industry, power plant, and recreation, will affect the behaviour 
and population structure of the fish [1]. As a result, it alters the population size of the fish, individual size, male to female ratio, and the proportions of mature, juvenile, and fish seeds [1] [22].

The spatial distribution in the Sempor reservoir is correlated with the quality of water as an environmental factor. The multivariate analysis using software Past 3 showed that the water quality in all stations had different physical elements (temperature, clarity, and depth), but the other parameters are generally similar. From spatial properties, it is estimated that water quality is not the only main contributing factor to the distribution of C.striata in the Sempor reservoir; in fact, it is affected more by fish behaviour in selecting their habitat. C.striata are abundant in shallow waters, so it is associated with high clarity and temperature. The transparency value is related to the TSS parameter. According to [27], the lowest the suspended solid (TSS), the higher the transparency, and vice versa. KW station had the last transparency $(0,3-0,8 \mathrm{~m})$ and the highest TSS $(147,25 \mathrm{mg} / \mathrm{l})$, but the TSS remains suitable with the standard quality mentioned in PP RI No 22 of 2021 class III and IV, namely $400 \mathrm{mg} / \mathrm{L}$. KW station is the estuary of Mampang River and Kedungjati River, so the suspended particles from the river neighbourhood are carried away by the water. As a result, the water turbidity in the inlet of Kedungwringin River is higher, thus higher TDS than the other stations. Therefore, this study supports the correlation between the abundance of C.striata and water quality parameters.

Based on the biplot of water quality and the abundance of C.striata, it is evident that TSS and TDS in KW station and DO in BK station are positively contributed to the abundance of C.striata. In contrast, the water flow speed has a negative contribution. The depth of the KW station is low $(<2 \mathrm{~m})$, so the clarity is high, and TSS concentration is below the threshold for fish living with the highest abundance. Therefore, the KW station is a suitable habitat for C.striata. Previous studies by [1] and [12] reported that snakehead fish seeds are abundant with grass or aquatic plants and shrubs soaked in the water at $40 \mathrm{~cm}$ depth and tend to prefer dark, muddy places with calm current or rocky beds for hiding. Channa striata are generally found in swamps, inland freshwater, or low-altitude rivers with a depth of 1-2 m [24]. C.striata are mainly caught in KW and KS stations with a low depth, muddy substrate, and calm flow ( $<1 \mathrm{~m} /$ second). Meanwhile, BK and WO stations had a high DO and low TSS, indicating a higher water depth, i.e., $6,1-8,7 \mathrm{~m}$ and 5,2-8,3m, respectively, compared to $\mathrm{KW}$ station $(0,5-1 \mathrm{~m})$. Therefore, the abundance of C.striata is relatively lesser than the KW station. Also, it shows that BK and WO stations are not

\section{Conclusion}

C.striata was vastly distributed in Sempor Reservoir from the inlets through the outlets with length- and weight-frequency distribution that ranged between 110-390 mm and 12-558 g, respectively. Varied weights of snakehead fish caught in the KW station indicated periodic recruitment, while bigger fish were mainly caught from the BK station. The highest abundance of snakehead fish was spotted in KW station, while the lowest was in BK station. The percentage of female fish was higher than that of the male, but there was a balanced male to female ratio in all five stations of Sempor Reservoir. PCA result showed that the distribution of C.striata was more affected by the fish behaviour in selecting their habitat than the water temperature, depth, and transparency. In general, the quality of water in Sempor Reservoir remains under the standard quality for fisheries. 


\section{References}

1. N. Muflikhah, Bawal Widya Ris. Perikan. Tangkap 1, 5 (2017)

2. Irmawati, J. Tresnati, Nadiarti, B. Yunus, Prosiding Simp. Nas. Kelaut. and Perikan. ke 4. 24-38 (2017)

3. A. Nuryanto, D. Bhagawati, M.N. Abulias, Indramawan, J. Iktiologi Indones. 12, 2 (2012)

4. A. Nuryanto, D. Bhagawati, M.N. Abulias, Indramawan, J. Iktiologi Indones. 15, 1 (2015)

5. M. Puspaningdiah, Solichin, A. Ghofar, J. Maquares 3, 4 (2014)

6. W. Prihatini, J. Sci. Innova. 1, 1 (2018)

7. G.N. Aliko, K.S. Da Costa, K.F.A. Ouattara, G. Gourene, Croat. J. Fish. 68, 2 (2010)

8. F. Mayer Pelicice. M.P.S. Pompeu, A.A Agostinho, A. Fish. 16, 4 (2015)

9. N. Setyaningrum, S. Sugiharto, P. Susatyo, Depik. 9, 3 (2020)

10. C. Umar, E. Kartamiharja, Pros. Semin. Nas. Ikan IV, 77-82 (2006)

11. S. Wahyuni. Sulistiono, R. Affandi, J. Bumi Lestari 14, 1 (2014)

12. N. Listyanto, S. Andriyanto, Media Akuakultur 4, 1 (2009)

13. D.I. Roesma, Pros. Semirata FMIPA Univ. Lampung, 197-204 (2013)

14. R.K.J. Hadiaty, Iktiologi Indones. 1, (2001)

15. I.G.N.A.P. Yudha, I.W. Arya, S.A.M.P. Suryani, Gema Argo. 23, 1 (2018)

16. S. Makmur, D. Prasetyo, J. Ilmu-Ilmu Perair. and Perikan. Indones. 13, 1 (2006)

17. N. Gogoi, L.P. Hazarika, S.P. Biswas, J. Environ. Biol. 37, 369-374 (2016)

18. S. Mian, M.H. Wahab, A.W. Shah, Int. J. Fish. Aquat. Stud. 5, 1 (2017)

19. K. Li, B. Shieh, Y. Chiu, H. Da-Ji, S. Liang, Zool. Stud. 55, 1-34 (2016)

20. E. Selviana, R. Affandi, M.M. Kamal, Ilmu Pertan. Indones. 25, 1(2020)

21. A. Saputra, M.H.F. Ath-thar, R. Samsudin, F.P. Putri A.V. Prakoso. Ber. Biol. 16, 3 (2017)

22. Z. Fahmi, S. Nurdawati, F. Supriyadi, Ind. Fish. Res. J. 19, 1 (2013)

23. S. Nurdawati , A. Rais, Hukmanan, F. Supriyadi, Bawal. 6, 3 (2014)

24. S. Makmur, M.F. Raharjo, S. Sukimin, J. Iktiologi Indones. 3, 2 (2003)

25. J. Nakajima, T. Ohata, N. Onikura, Folia Zool. 60, 4 (2011)

26. M. Čech, J. Kubečka, J. Frouzová, V. Draštík, M. Kratochvíl, J. Matěna, J.J. Hejzlar, J. Fish Biol. 70, 1 (2007)

27. E. Supriyantini, R.A.T. Nuraini, A.P. Fadmawati, Oseanografi Mar. 6, 1(2017)

28. R. Froese, D. Pauly, FishBase, www.fishbase.org (2021) 